\title{
Isolation and Restriction Endonuclease Analysis of Mycobacterial DNA
}

\author{
By RUBINA PATEL,${ }^{1} \dagger$ JAMES T. KVACH, ${ }^{2}$ and PHOEBE MOUNTS $1{ }^{*}$ \\ ${ }^{1}$ Department of Immunology and Infectious Diseases, The Johns Hopkins University, \\ School of Hygiene and Public Health, Baltimore, MD 21205, USA \\ 2 Leonard Wood Memorial, American Leprosy Foundation, Department of Immunology and \\ Infectious Diseases, The Johns Hopkins University, School of Hygiene and Public Health, \\ Baltimore, MD 21205, USA
}

(Received 3 May 1985; revised 31 July 1985)

\begin{abstract}
A method for the isolation of DNA from mycobacteria propagated in vitro is described that utilizes organic solvents to extract lipoidal components from the outer membrane, and digestion with a protease (nagarse) and lysozyme to penetrate the cell wall. The mycobacterial cells were lysed by the addition of detergent and the DNA was purified by digestion with pronase, sequential phenol and chloroform extractions, and digestion with RNAase A. The isolated DNA, which was obtained in good yields, was of a relatively high $M_{\mathrm{r}}$ and could be readily digested by restriction endonucleases. By this method, the genomes of Mycobacterium avium, $M$. intracellulare, $M$. lepraemurium, ' $M$. lufi', $M$. marinum, $M$. phlei, $M$. scrofulaceum, $M$. smegmatis and $M$. tuberculosis were isolated and the restriction endonuclease digestion patterns analysed. Each species could be distinguished by the digestion patterns, indicating that this approach can be used for identifying mycobacterial species. This approach is also sufficiently sensitive to differentiate strains since we were able to distinguish two independently isolated strains of $M$. tuberculosis, $\mathrm{H} 37$ and $\mathrm{H} 4$. In addition, no evidence was obtained for the presence of methylcytosine residues in the sequences $5^{\prime}$.CCGG. $3^{\prime}, 5^{\prime}$.CCCGGG. $3^{\prime}, 5^{\prime}$.CC(A/T)GG. $3^{\prime}$ or for methyladenine at $5^{\prime}$.GATC. $3^{\prime}$ in the DNA of the nine mycobacterial species examined using pairs of restriction enzymes that recognize and cleave at the same nucleotide sequence but differ in their sensitivity to 5 -methylcytosine or ${ }^{6} \mathrm{~N}$-methyladenine.
\end{abstract}

\section{INTRODUCTION}

Members of the genus Mycobacterium are widespread in nature and range from soil-dwelling saprophytes to pathogens of man and animals. Mycobacteria are defined on the basis of impermeability to basic dyes, but once stained, they retain dye even in the presence of acidified organic solvents (Vestal, 1975). This characteristic of being acid-fast is presumably a result of their lipid-rich cell wall. The identification of clinical and environmental isolates is usually based on analysis of phenotypic characters (for reviews see Barksdale\& Kim, 1977; Wolinsky, 1979). Since it is possible that the morphology and biosynthetic capabilities of mycobacteria may vary depending on culture conditions and strain differences within a species, the most reliable method of identification would be at the DNA level. Previous studies have examined the guanine plus cytosine content of mycobacterial DNA (Hill, 1966; Imaeda et al., 1982; Wayne \& Gross, 1968b) and DNA hybridization in solution (Bradley et al., 1973; Gross \& Wayne, 1970; Imaeda et al., 1982) as a means of identifying and differentiating species. It is now feasible to characterize strains of micro-organisms at the genomic level by the unique restriction endonuclease digestion patterns of their DNA. This technology requires the isolation of high $M_{\mathrm{r}}$ DNA from mycobacteria, which is difficult because of the impermeable cell wall. Various

† Present address: Department of Tropical Public Health, Harvard School of Public Health, 665 Huntington Avenue, Boston, MA 02115, USA. 
methods of isolating DNA from mycobacteria have been reported (Baess, 1974; Mizuguchi \& Tokunaga, 1970; Wayne \& Gross, 1968a) which generally utilize procedures of cell disruption which may shear DNA. Therefore, we have developed a method for extracting DNA in good yields from mycobacteria cultivated in vitro which is of relatively high $M_{\mathrm{r}}$ and can be digested by restriction endonucleases. We report here the isolation and restriction enzyme cleavage analysis of DNA from Mycobacterium avium, a member of the $M$. avium-intracellulare-scrofulaceum (MAIS) complex which causes tuberculosis in birds and has been included as an opportunistic pathogen in patients with acquired immune deficiency (Macher et al., 1983; Zakowski et al., 1982); $M$. intracellulare, which is a rare pathogen for chickens but also causes chronic, and sometimes fatal, pulmonary disease in humans; $M$. lepraemurium, which is the aetiological agent of rodent leprosy; $M$. marinum, which causes chronic skin lesions in humans; $M$. scrofulaceum, a common cause of lymphadenitis in children; $M$. tuberculosis, the cause of human tuberculosis; and three species of soil saprophyte, $M$. phlei, $M$. smegmatis and ' $M$. lufu'. These nine species could be distinguished by the restriction endonuclease digestion patterns of purified DNA as visualized after agarose gel electrophoresis. Using eight different restriction enzymes we could not detect differences between avirulent and virulent strains of $M$. tuberculosis $\mathrm{H} 37$ but the independent isolates $\mathrm{H} 37$ and $\mathrm{H} 4$ could be distinguished.

\section{METHODS}

Bacterial strains. Mycobacterium phlei ATCC 11758, M. scrofulaceum ATCC 19981, M. smegmatis ATCC 19420, M. tuberculosis H37Ra ATCC 25177, and M. tuberculosis H37Rv ATCC 25618 were obtained from the American Type Culture Collection. M. tuberculosis H4Ra TMC 204 was acquired from the Trudeau Mycobacterial Culture Collection, National Jewish Hospital and Research Center, Denver, Colo., USA. M. lepraemurium (Hawaiian) and ' $M$. lufi' L-868 were provided through the courtesy of Dr A. Dhople, Florida Institute of Technology, USA. M. marinum TMC 1218 and $M$. intracellulare ATCC 13950 were provided through the courtesy of Dr T. Hadfield, Armed Forces Institute of Pathology, Washington, DC, USA. M. avium (no. 8063, Pasteur Institute reference strain) and an independent isolate (no. 214) were sent from Belgium by Dr F. Portaels. Stock cultures were maintained at $4{ }^{\circ} \mathrm{C}$ on Lowenstein-Jensen slants (BBL). Mycobacteria were grown in $1000 \mathrm{ml}$ Dubos broth base (Difco) containing $0.4 \%$ glycerol (Fisher Scientific). The cultures were incubated at $37^{\circ} \mathrm{C}$ on a rotary shaker and harvested at late exponential or early stationary phase growth. $M$. lepraemurium, adapted to growth on Lowenstein-Jensen slants by Dr A. Dhople, was harvested by scraping cells from the surface of the medium. Escherichia coli MM294 was propagated in Luria broth (Lennox, 1955).

DNA isolations. Mycobacterial cells were recovered by centrifugation at $12000 \mathrm{~g}$ for $30 \mathrm{~min}$ at $4{ }^{\circ} \mathrm{C}$ and washed once in $50 \mathrm{~mm}$-Tris/HCL (pH 8.0), $100 \mathrm{~mm}-\mathrm{EDTA}, 150 \mathrm{~mm}-\mathrm{NaCl}$ (TEN). Bacteria were resuspended in 1 to $5 \mathrm{ml}$ TEN depending on the size of the pellet. Light petroleum (LP; b.p. $35-60^{\circ} \mathrm{C}$ ) and $\mathrm{CHCl}_{3}$ were added to the bacterial suspension in a 3:1:1 (LP: $\mathrm{CHCl}_{3}:$ TEN, by vol.) ratio. After vortex mixing and rocking on a Thermolyne Speci-Mix (Sybron Corporation) for $15 \mathrm{~min}$, the organic phase was centrifuged at $12000 \mathrm{~g}$. This extraction was repeated until the organic phase was clear. The extracted cell pellet was resuspended in 1 to $2 \mathrm{ml}$ TEN depending on the size of the cell pellet. Nagarse (protease, type VII, bacterial; Sigma), which was used previously to isolate cell wall components (Takeya \& Hisatsune, 1963), was added to the bacterial suspension to a final concentration of $10 \mathrm{mg} \mathrm{ml}^{-1}$ and incubated at $37^{\circ} \mathrm{C}$ for 2 to $4 \mathrm{~h}$. Lysozyme (Sigma) was added $\left(50 \mathrm{mg} \mathrm{ml}^{-1}\right.$ ) and incubated at $50^{\circ} \mathrm{C}$ for 2 to $4 \mathrm{~h}$. Bacterial lysis was completed by adding SDS to $1 \%(\mathrm{w} / \mathrm{v})$ and pronase B (Calbiochem-Behring) to $3 \mathrm{mg} \mathrm{ml}^{-1}$. The lysate was incubated at $37^{\circ} \mathrm{C}$ for 12 to $36 \mathrm{~h}$ with additions of pronase B $\left(3 \mathrm{mg} \mathrm{ml}^{-1}\right)$ at $12 \mathrm{~h}$ intervals. DNA was purified by sequential extractions with equal volumes of phenol (Bethesda Research Laboratories) saturated with TEN, and chloroform/isoamyl alcohol $(24: 1, \mathrm{v} / \mathrm{v})$. The DNA preparation was dialysed for $48 \mathrm{~h}$ against $10 \mathrm{mM}-\mathrm{Tris} / \mathrm{HCl}(\mathrm{pH} 7.5), 1 \mathrm{mM}-\mathrm{EDTA}(\mathrm{pH} 7.4), 150 \mathrm{mM}-\mathrm{NaCl}$ at $4{ }^{\circ} \mathrm{C}$, digested with RNAase A $\left(20 \mu \mathrm{g} \mathrm{ml}^{-1}\right.$; Calbiochem-Behring) for $2 \mathrm{~h}$ at $37^{\circ} \mathrm{C}$ and sequentially extracted with phenol and chloroform/isoamyl alcohol. The DNA was either dialysed exhaustively against $10 \mathrm{mM}-\mathrm{Tris} / \mathrm{HCl}$ (pH 7.5), $1 \mathrm{mM}$ EDTA (TE) or was precipitated by adding $\mathrm{NaCl}$ to $0.3 \mathrm{M}, 2.5$ volumes ethanol or 0.56 volume 2-propanol and placed at $-20^{\circ} \mathrm{C}$ overnight. The DNA was pelleted by centrifugation and redissolved in TE at $4^{\circ} \mathrm{C}$. The concentration and purity of DNA was determined in a Gilford 250 spectrophotometer. If the $280 / 260$ or 240/260 readings were greater than $0.5 \pm 0.1$, the DNA was treated further with SDS and pronase B, extracted with phenol and chloroform/isoamyl alcohol and precipitated with alcohol or dialysed against TE. DNA was isolated from cultures of $\boldsymbol{M}$. avium and $\boldsymbol{M}$. marinum which were harvested by centrifugation, frozen rapidly in liquid nitrogen, and stored at $-70^{\circ} \mathrm{C}$. The pellet was thawed, resuspended in TEN and extracted as described above. $E$. coli cultures were harvested by centrifugation, washed once with TEN, incubated for $10 \mathrm{~min}$ at $4^{\circ} \mathrm{C}$ with $10 \mu \mathrm{g}$ 
lysozyme $\mathrm{ml}^{-1}$ and lysed by the addition of SDS to one-tenth volume of $10 \%(\mathrm{w} / \mathrm{v})$ SDS. The DNA was purified as described above.

Restriction endonuclease digestion and gel electrophoresis. Using conditions specified by the vendor, DNA was digested with restriction endonucleases purchased from Bethesda Research Laboratories and New England Biolabs. Digestion was terminated by heating at $65^{\circ} \mathrm{C}$ for $5 \mathrm{~min}$ or by adding SDS to $0.05 \%$. Bacteriophage $\lambda c I 857$ (Bethesda Research Laboratories) digested with restriction endonucleases as indicated was used as size markers (Syzbalski \& Syzbalski, 1979; Thomas \& Davis, 1975). The digested DNA was size-fractionated by agarose gel electrophoresis, in $40 \mathrm{~mm}$-Tris/ $\mathrm{HCl}(\mathrm{pH} 7.5), 20 \mathrm{~mm}$-sodium acetate, $1 \mathrm{~mm}$-EDTA. The gel was stained in ethidium bromide solution $\left(0 \cdot 5 \mu \mathrm{g} \mathrm{ml}^{-1}\right)$ and photographed under ultraviolet light with Polaroid type $57 \mathrm{film}$.

Remotal of polysaccharides. The procedure described by Hill et al. (1972) was followed, with minor modifications. Cetyltrimethylammonium bromide (CTAB; Sigma) was dissolved in $0.4 \mathrm{M}-\mathrm{NaCl}$ to give a $5 \%(\mathrm{w} / \mathrm{v})$ solution, and added to the DNA solution (2:5). After allowing for precipitation of DNA-CTAB for 15 min at room temperature, a few drops of the CTAB solution were added to ensure complete precipitation. After centrifugation, the pellet was washed twice in $0.4 \mathrm{M}-\mathrm{NaCl}$ and dissolved in $1 \mathrm{M}-\mathrm{NaCl}$. The DNA solution was extracted with chloroform/isoamyl alcohol until no precipitate was visible at the interface. DNA was precipitated by adding 3 volumes $95 \%(\mathrm{v} / \mathrm{v})$ ethanol and redissolved in $0.7 \mathrm{M}-\mathrm{NaCl}$. CTAB in $0.7 \mathrm{M}-\mathrm{NaCl}$ was added to $1 \%$ and precipitation was allowed for $30 \mathrm{~min}$ at room temperature. After centrifugation, 3 volumes $95 \%$ ethanol were added to the supernatant fluid. The DNA was redissolved in TE and dialysed exhaustively against TE at $4{ }^{\circ} \mathrm{C}$.

\section{RESULTS \\ DNA yield}

Typical results of the yield of DNA from 12 mycobacterial strains, isolated as described in Methods, are presented in Table 1. Using our method, DNA was obtained reproducibly in sufficient quantities from the nine species tested. Variation in the quantity of DNA obtained per $\mathrm{ml}$ of culture medium may be a consequence of cell density at the time of harvest. The yield [mg DNA ( $\mathrm{g}$ wet wt cells) ${ }^{-1}$ ] from ' $M$. lufu' was also lower than for the other mycobacteria. The size of the purified DNA was determined by agarose gel electrophoresis. Mycobacterial DNA (1 $\mu \mathrm{g})$ and digested bacteriophage $\lambda(49 \mathrm{~kb})$, which was used as a size marker, were electrophoresed on a $1 \%$ agarose gel as described in Methods. If there was evidence of extensive degradation, i.e. fluorescence seen throughout the track, the DNA preparation was discarded. Degradation, presumably by endogenous nucleases, was only an occasional problem. Undigested DNA of $M$. tuberculosis H37Ra, $M$. smegmatis and $M$. phlei is shown in Fig. 5, lanes $b, f$ and $j$, respectively.

Table 1. Yield of DNA from 12 mycobacterial strains

\begin{tabular}{|c|c|c|}
\hline \multirow[b]{2}{*}{ Strain } & \multicolumn{2}{|c|}{ DNA yield } \\
\hline & $\begin{array}{l}\text { [mg DNA (g wet } \\
\left.\text { wt cells) }{ }^{-1}\right]^{*}\end{array}$ & $\begin{array}{c}{[\mu \mathrm{g} \text { DNA }} \\
\left.(\mathrm{ml} \text { culture })^{-1}\right] \dagger\end{array}$ \\
\hline M. avium (Pasteur no. 8063) & 1.6 & $1 \cdot 2$ \\
\hline M. avium no. 214 & $1 \cdot 3$ & $1 \cdot 0$ \\
\hline M. intracellulare ATCC 13950 & $1 \cdot 1$ & $2 \cdot 8$ \\
\hline 'M. Iufu' L-868 & $0 \cdot 3$ & 0.6 \\
\hline M. marinum TMC 1218 & $1 \cdot 1$ & $2 \cdot 5$ \\
\hline M. phlei ATCC 11758 & $1 \cdot 5$ & $1 \cdot 3$ \\
\hline M. scrofulaceum ATCC 19981 & ND & 1.4 \\
\hline M. smegmatis ATCC 19420 & $1 \cdot 2$ & $1 \cdot 8$ \\
\hline M. tuberculosis H4Ra TMC 204 & ND & $0 \cdot 8$ \\
\hline M. tuberculosis H37Ra ATCC 25177 & $1 \cdot 2$ & $1 \cdot 5$ \\
\hline M. tuberculosis H37Rv ATCC 25618 & $2 \cdot 0$ & $1 \cdot 7$ \\
\hline M. lepraemurium (Hawaiian) & ND & $20 \cdot 0 \ddagger$ \\
\hline
\end{tabular}

ND, Not determined.

* Bacteria were grown to late exponential or early stationary phase in $1000 \mathrm{ml}$ Dubos broth base with $0.4 \%$ glycerol. The pellet obtained after harvesting the cells was weighed in a tared tube.

+ The DNA concentration was determined spectrophotometrically.

$\ddagger 20 \mu \mathrm{g}$ per slant. $M$. lepraemurium was grown on 20 Lowenstein-Jensen slants and was harvested by scraping the cells from the surface of the medium. 


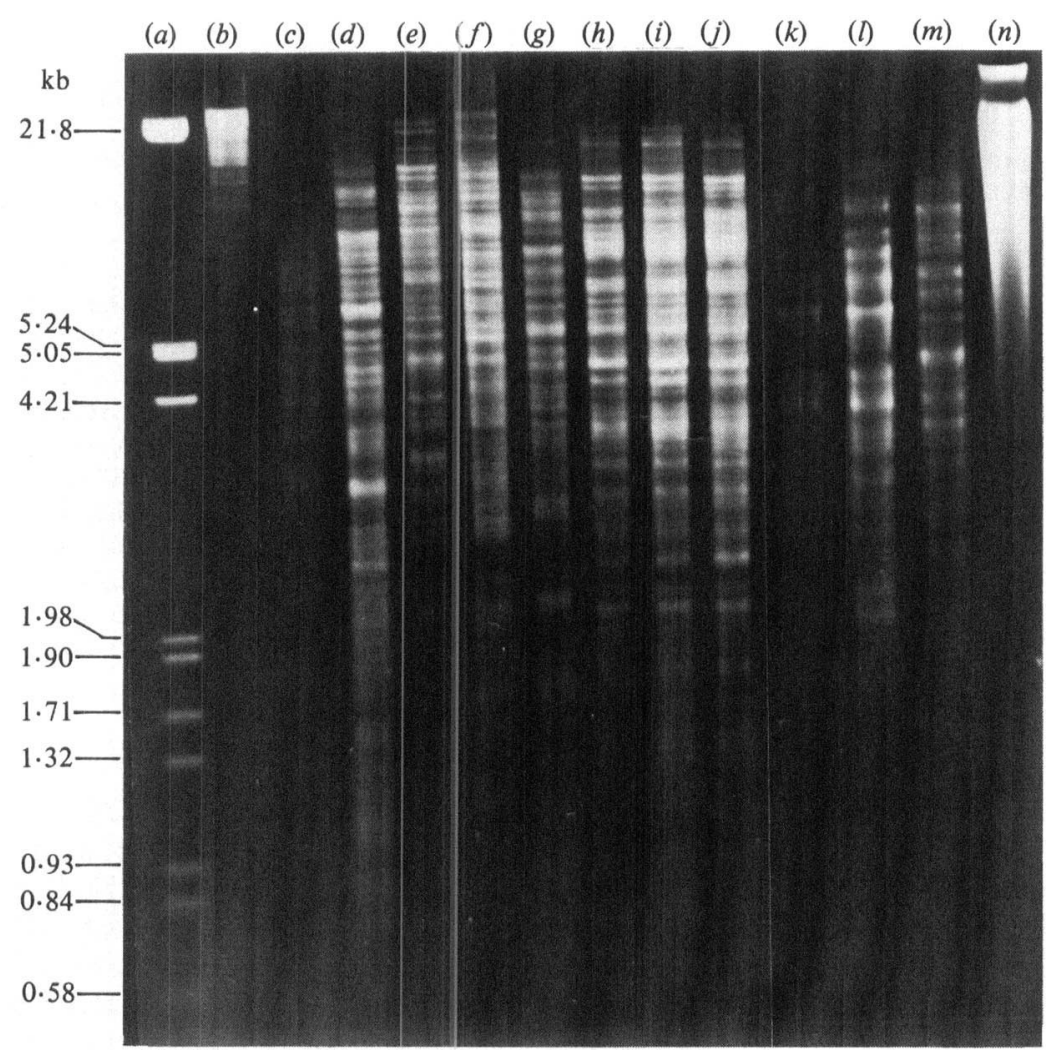

Fig. 1. Mycobacterial DNA digested with restriction endonuclease BamHI and size-fractionated on a $1 \%$ agarose gel. For each digest $3 \mu \mathrm{g}$ DNA was used. Bacteriophage $\lambda$ DNA digested sequentially with HindIII and EcoRI was used as size markers (lane $a$ ). Lanes: (b) E. coli; $(c)$ M. smegmatis; (d) M. phlei; (e) M. scrofulaceum; ( $f$ ) M. marinum; $(g)$ M. lepraemurium; $(h)$ M. tuberculosis H37Rv; $(i)$ M. tuberculosis H37Ra; $(j) M$. tuberculosis H4Ra; $(k) M$. avium no. $214 ;(l) M$. avium no. 8063; $(m)$ M. intracellulare; $(n)$ 'M. lufu'.

\section{Restriction endonuclease analysis}

The enzymes BamHI, EcoRI, HindIII and PstI were used to establish digestion patterns of the mycobacteria. DNA $(3 \mu \mathrm{g})$ from each strain was incubated with 6 units of enzyme for $2 \mathrm{~h}$ and analysed by gel electrophoresis as described above. The four restriction endonucleases allowed for species differentiation at the DNA level. For example, Fig. 1 shows an ethidium bromide stained gel obtained with DNA digested with BamHI. Each species was distinguished by its unique digestion pattern [for example, compare $M$. phlei (lane $d$ ) with $M$. scrofulaceum (lane $e$ )]. However, there were no apparent differences between $M$. tuberculosis strains H37Rv (lane $h$ ), H37Ra (lane $i$ ) and H4Ra (lane $j$ ). Similarly, we could not detect any differences between the BamHI digestion patterns of two isolates of $M$. avium (lanes $k$ and $l$ ).

PstI cleaved the mycobacterial DNAs (Fig. 2) except for $M$. lepraemurium DNA (lane $g$ ). Again, each species of mycobacterium was distinguishable by its digestion pattern but there were no apparent differences among $M$. tuberculosis strains H37Rv (lane $h$ ), H37Ra (lane $i$ ) and H4Ra (lane $j$ ) or between two independent isolates of $M$. avium (lanes $k$ and $l$ ). The absence of digestion of $M$. lepraemurium DNA by Pst I was not due to inhibition of the enzyme by the DNA preparation, since this DNA was digested by other enzymes (e.g. BamHI; Fig. 1, lane g) and complete digestion was assayed by the addition of bacteriophage $\lambda$ DNA to the reaction. Although the $\lambda$ DNA was digested to completion, the $M$. lepraemurium DNA remained undigested (data not shown), demonstrating that the enzyme was not inhibited in trans. It seems 


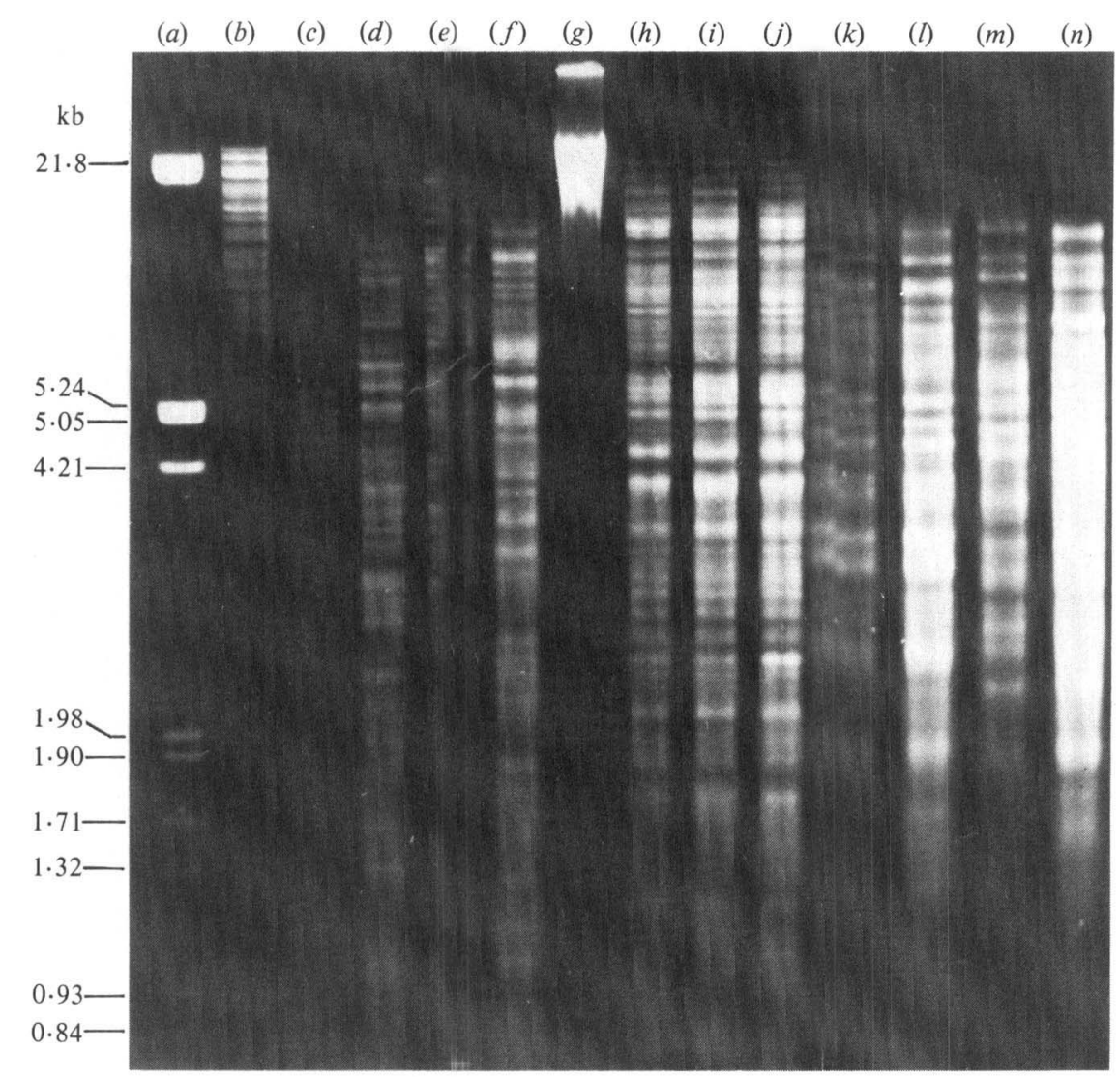

Fig. 2. Agarose gel electrophoresis through a $1 \%$ gel of $3 \mu \mathrm{g}$ mycobacterial DNA digested with PstI. Bacteriophage $\lambda$ DNA digested with HindIII and EcoRI was used as size markers (lane $a$ ). Lanes: (b) E. coli; (c) M. smegmatis; (d) M. phlei; (e) M. scrofulaceum; $(f) M$. marinum; $(g)$ M. lepraemurium;

(h) M. tuberculosis H37Rv; (i) M. tuberculosis H37Ra; (j) M. tuberculosis H4Ra; (k) M. avium no. 214;

(l) $M$. avium no. 8063; (m) $M$. intracellulare; $(n)$ ' $M$. lufu'.

unlikely that the recognition sequence for PstI is absent in $M$. lepraemurium DNA and the absence of enzyme digestion may be due to DNA modification at, or around, the recognition sequence.

Digestion of mycobacterial DNA with BamHI, EcoRI (data not shown) and PstI produced fragments ranging in size from a few hundred bp to more than $20000 \mathrm{bp}$. In contrast, the size of the DNA fragments produced by digestion with HindIII was relatively large, especially in $M$. smegmatis (Fig. 3, lane $c$ ), $M$. phlei (lane $d$ ), $M$. scrofulaceum (lane $e$ ), $M$. lepraemurium (lane $g$ ), $M$. tuberculosis H4Ra (lane $j$ ) and ' $M$. lufu' (lane $n$ ). Complete digestion was assayed by the addition of $\lambda$ DNA to that of $M$. tuberculosis H4Ra, ' $M$. lufu' and $M$. avium (Fig. 4, lanes $b, e$ and $h$, respectively). Although the $\lambda$ DNA was digested to completion, the mycobacterial DNA remained relatively undigested, demonstrating that the enzyme was not inhibited in trans from digesting the DNA. The resistance of DNA from $M$. tuberculosis H4Ra to digestion with HindIII (Fig. 3, lane $j$ ) distinguished it from that of strain H37Rv (lane $h$ ) and strain H37Ra (lane $i$ ). These results suggest that DNA from $M$. tuberculosis $\mathrm{H} 4 \mathrm{Ra}$ is modified by methylation at, or near, the HindIII recognition sequence and therefore is relatively resistant to digestion with HindIII.

Previous reports have noted the association of mycobacterial DNA with contaminating polysaccharides (Baess, 1974). The polysaccharide content in our DNA preparations, as 


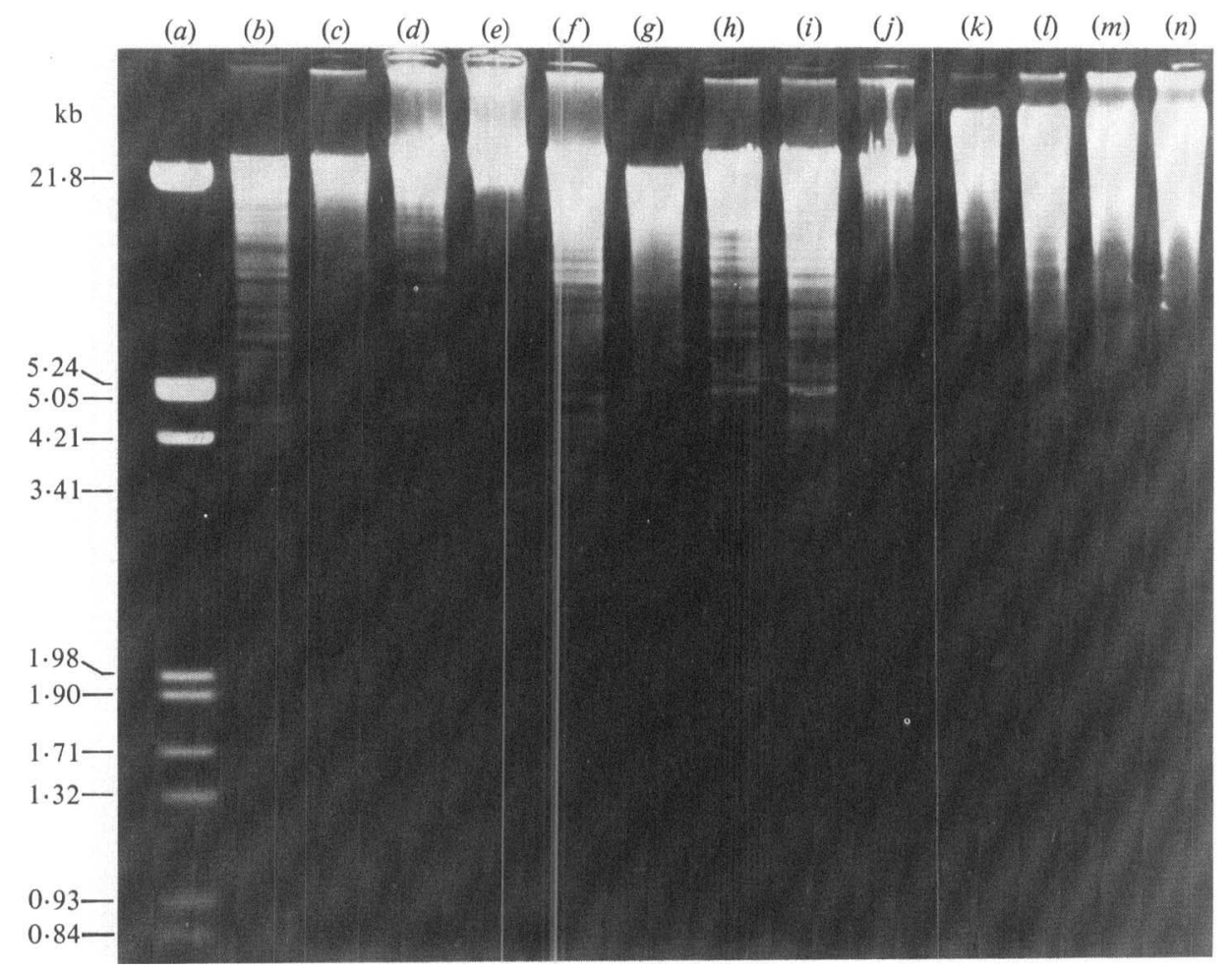

Fig. 3. Restriction endonuclease digests of mycobacterial DNA with HindIII, size-fractionated on a $1 \%$ agarose gel. Bacteriophage $\lambda$ DNA digested with Hind III and $E c o$ RI was used as size markers (lane a). Lanes: (b) E. coli; (c) M. smegmatis; $(d) M$. phlei; (e) M. scrofulaceum; $(f) M$. marinum; $(g) M$. lepraemurium; (h) M. tuberculosis H37Rv; $(i) M$. tuberculosis H37Ra; $(j) M$. tuberculosis H4Ra; $(k) M$. avium no. $214 ;(l)$ M. avium no. $8063 ;(m)$.M. intracellulare; $(n)$ ' $M$. lufu'.

determined by the anthrone hexose assay (Ashwell, 1957), ranged from $0.112 \mathrm{mg}(\mathrm{mg} \mathrm{DNA})^{-1}$ in $M$. phlei to $2.97 \mathrm{mg}$ (mg DNA) ${ }^{-1}$ in $M$. scrofulaceum. To determine if the polysaccharides affected digestion of DNA with restriction endonucleases, polysaccharides were removed from $M$. tuberculosis $\mathrm{H} 37 \mathrm{Ra}, M$. smegmatis and $M$. phlei; before precipitation with CTAB, they contained $1.64,0.708$ and $0.112 \mathrm{mg}$ polysaccharide $(\mathrm{mg} \mathrm{DNA})^{-1}$, respectively. No polysaccharides could be detected after CTAB precipitation. Degradation of DNA was evident after the elimination of polysaccharides (Fig. 5, lanes $c$ and $k$ ). DNA was digested with PstI before and after removal of the polysaccharides (lanes $d, e, h, i, l$ and $m$ ). No difference was seen in the restriction patterns. There was no correlation between the quantity of polysaccharides and the pattern of digestion with restriction enzymes.

\section{Methylation in mycobacterial DNA}

Methylation of nucleotides can be determined by using pairs of restriction enzymes which recognize the same nucleotide sequence but differ in their sensitivity to methylation at, or near, the recognition site (for review see Roberts, 1983). To examine the quantity and distribution of methylated nucleotides in mycobacterial DNA, $3 \mu \mathrm{g}$ DNA were digested with enzymes which differ in their sensitivity to methylation at a cytosine residue contained in their respective recognition sequences. HpaII and MspI recognize $5^{\prime}$. CCGG.3'; HpaII is sensitive to methylation at the internal cytosine residue whereas MspI is not (Roberts, 1983); SmaI, sensitive to methylation at $\mathrm{CpG}$, recognizes and cleaves $5^{\prime}$.CCCGGG.3'; XmaI recognizes the same sequence but cleaves asymmetrically, i.e. 5'.CCCGGG.3' and is not sensitive to 


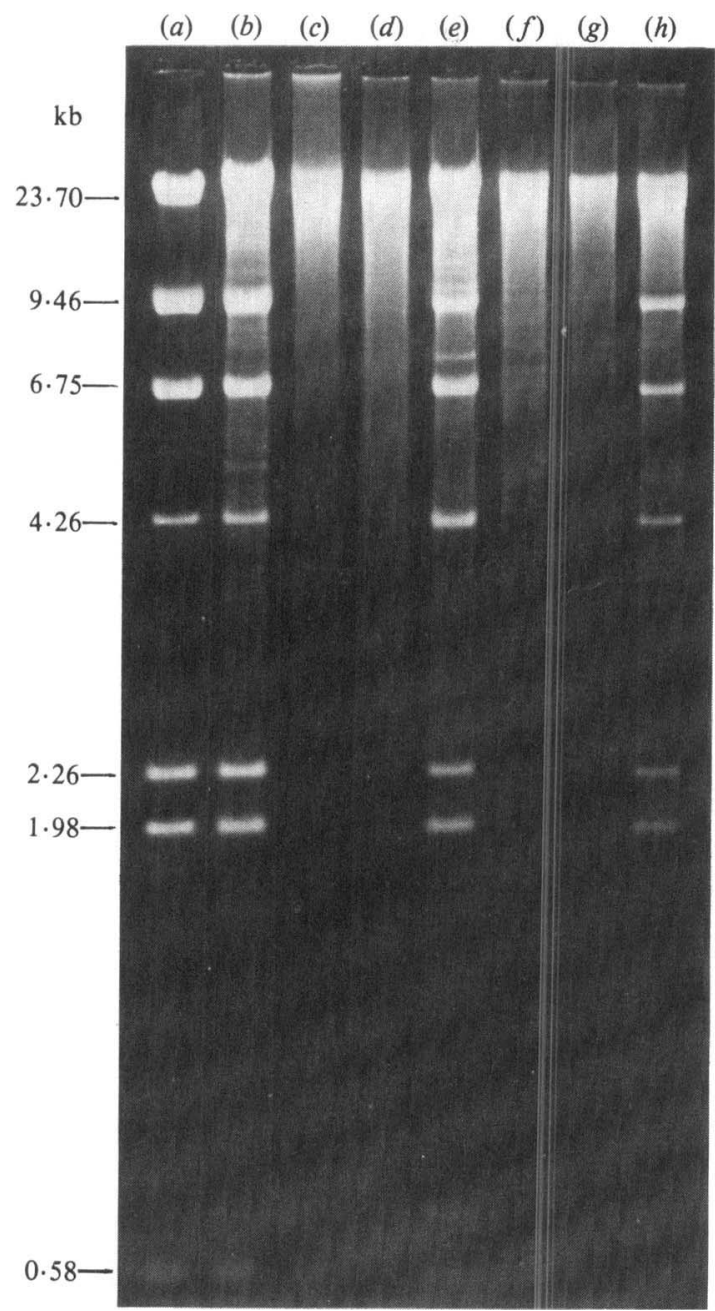

Fig. 4. Assay for HindIII activity by incubating mycobacterial and $\lambda$ DNA. Mycobacterial DNA $(1 \mu \mathrm{g})$ was added to $1 \mu \mathrm{g} \lambda$ DNA and digested with HindIII. Bacteriophage $\lambda$ DNA digested with $H i n d I I I$ was used as a control (lane $a$ ). Lanes: $(b)$ $M$. tuberculosis H4Ra plus $\lambda$, HindIII; (c) 'M. lufu' undigested; (d) 'M. lufu', HindIII; (e) 'M. lufu' plus $\lambda$, HindIII; $(f) M$. avium no. 8063, HindIII; $(g) M$. avium no. 214, HindIII; (h) M. avium no. 8063 plus $\lambda$, HindIII. (i) $\lambda$, HindIII/EcoRI.

methylation (Youssoufian \& Mulder, 1981). Since identical patterns were observed for each mycobacterial strain (data not shown), it may be assumed that 5-methylcytosine $\left(\mathrm{m}^{5} \mathrm{C}\right)$ is not present in these sequences. A third pair of enzymes, Bst NI and EcoRII, recognizes and cleaves the nucleotide sequence $5^{\prime} . \mathrm{CC}(\mathrm{A} / \mathrm{T}) \mathrm{GG} \cdot 3^{\prime}$ (Roberts, 1983). Bst $\mathrm{NI}$ is not sensitive to $\mathrm{m}^{5} \mathrm{C}$ at this sequence while $E c o \mathrm{RII}$ is sensitive to methylation at this sequence. For example, $E$. coli DNA was readily digested by Bst NI (Fig. 6, lane $b$ ) but not by EcoRII (lane $c$ ) because this strain contains methylated DNA. 5-Methylcytosine could not be detected at this site in the mycobacterial DNA examined and no difference was apparent in the digestion patterns of $M$. tuberculosis $\mathrm{H} 37 \mathrm{Ra}$ and $\mathrm{H} 37 \mathrm{Rv}$ when digested with Bst NI and EcoRII, which indicated that $\mathrm{m}^{5} \mathrm{C}$ is not contained in this recognition site. However, it was possible to differentiate independently isolated strains of $M$. tuberculosis ( $\mathrm{H} 4$ and $\mathrm{H} 37)$ with Bst NI. A band of approximately $4.2 \mathrm{~kb}$ is present in $M$. tuberculosis $\mathrm{H} 37$ digested with $B s t$ NI (lane $f$ ) or EcoRII (lane $g$ ) but is absent in $M$. tuberculosis $\mathrm{H} 4$ digested with $B s t$ NI (lane $h$ ). In addition, strain $\mathrm{H} 4$ appears to contain some methylation since the DNA is not digested by EcoRII (lane $i$ ) to the same extent as it is by BstNI (lane $h$ ). In order to examine the quantity and distribution of $N^{6}$ methyladenine $\left(\mathrm{m}^{6} \mathrm{~A}\right)$ in the mycobacterial strains in the present study, enzymes were utilized which recognize the same nucleotide sequence but differ in their sensitivity to methylation. 


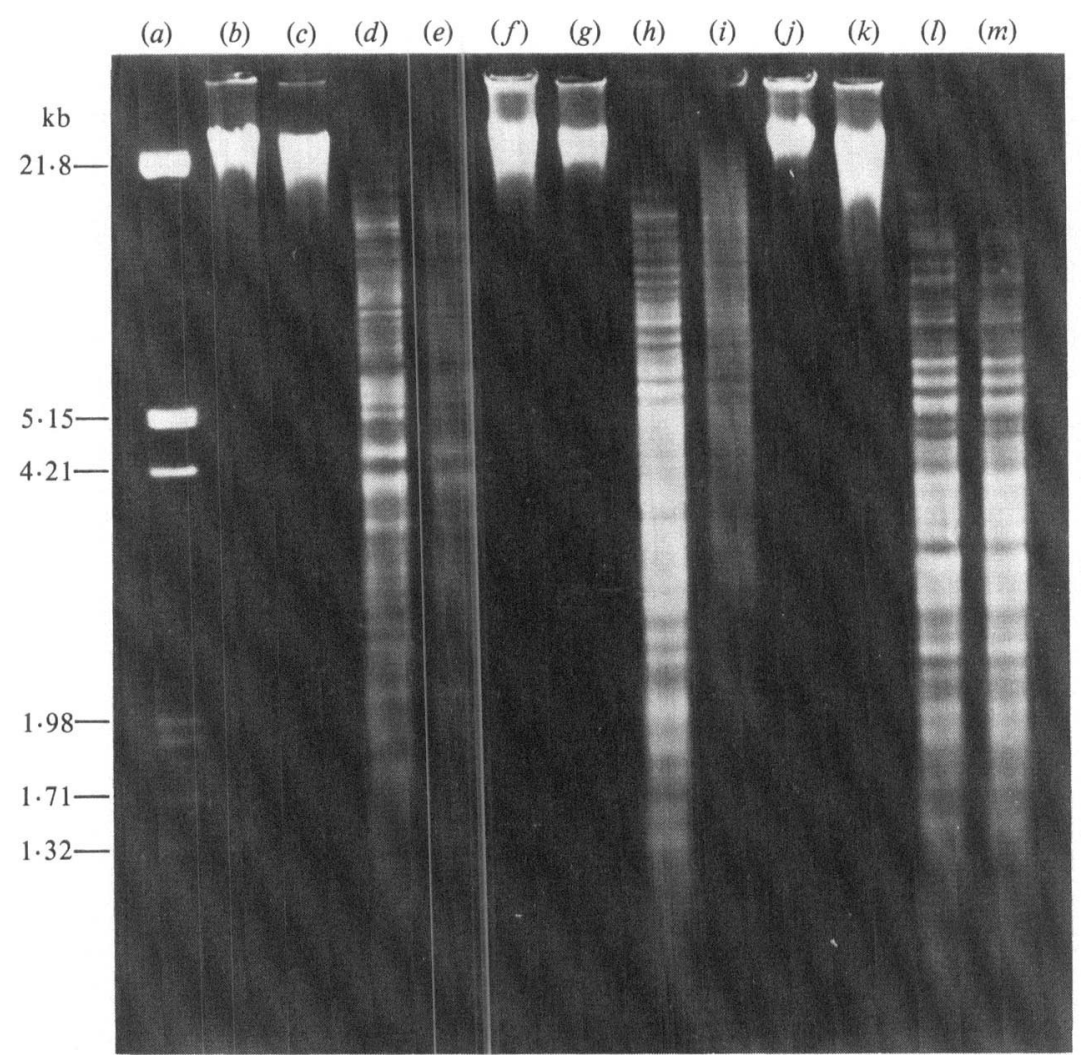

Fig. 5. DNA from $M$. tuberculosis H37Ra, $M$. smegmatis and $M$. phlei, before and after elimination of polysaccharides by precipitation with cetyltrimethylammonium bromide (CTAB). Undigested DNA $(2 \mu \mathrm{g})$ and $3 \mu \mathrm{g}$ DNA digested with Pst $\mathrm{I}$ were electrophoresed through a $1 \%$ agarose gel. Bacteriophage $\lambda$ DNA digested with HindIII and EcoRI was used as size markers (lane $a$ ). Lanes: (b) $M$. tuberculosis H37Ra, before CTAB, undigested; (c) $M$. tuberculosis H37Ra, after CTAB, undigested; $(d) M$. tuberculosis H37Ra, before CTAB, PstI; (e) $M$. tuberculosis H37Ra, after CTAB, PstI; $(f) M$. smegmatis, before CTAB, undigested; $(g) M$. smegmatis, after CTAB, undigested; $(h) M$. smegmatis, before CTAB, PstI ; (i) $M$. smegmatis, after CTAB, PstI ; $(j) M$. phlei, before CTAB, undigested; $(k) M$. phlei, after CTAB, undigested; $(l) M$. phlei, hefore CTAB, Pst $;(m) M$. phlei, after CTAB, PstI.

Sau3AI and $M b o$ I recognize the sequence $5^{\prime}$.GATC.3'. Sau3AI digests regardless of $\mathrm{m}^{6} \mathrm{~A}$, whereas $M b o$ I does not cleave if the A residue is methylated. DNA $(3 \mu \mathrm{g})$ from each strain was digested with $S a u 3 \mathrm{AI}$ or $\mathrm{MboI}$ and loaded on a $2.5 \%$ agarose gel. No difference in restriction patterns between $S a u 3 A I$ and $M b o$ I was evident for any of the species, which indicated that $\mathrm{m}^{6} \mathrm{~A}$ was not present in this particular sequence of nucleotides (data not shown).

\section{DISCUSSION}

We have compared the restriction endonuclease digestion patterns of DNA isolated from nine species of mycobacteria cultured in vitro. To facilitate this type of analysis it was necessary to develop a method for the isolation of undegraded DNA in good yields that was susceptible to cleavage by restriction enzymes. As demonstrated in Table 1, the average yield of DNA obtained in this study was comparable to that obtained by Baess (1974) [1 mg DNA (g wet wt cells $)^{-1}$, Mizuguchi \& Tokunaga (1970) $\left(1.34 \mathrm{mg} \mathrm{DNA} \mathrm{1}^{-1}\right)$ and Wayne \& Gross $(1968 a)$ $\left[0.67 \mathrm{mg}\right.$ DNA ( $\mathrm{g}$ wet wt cells) $\left.{ }^{-1}\right]$. Our results indicate that polysaccharides do not interfere with digestion of mycobacterial DNA by restriction endonucleases, thereby allowing the omission of 


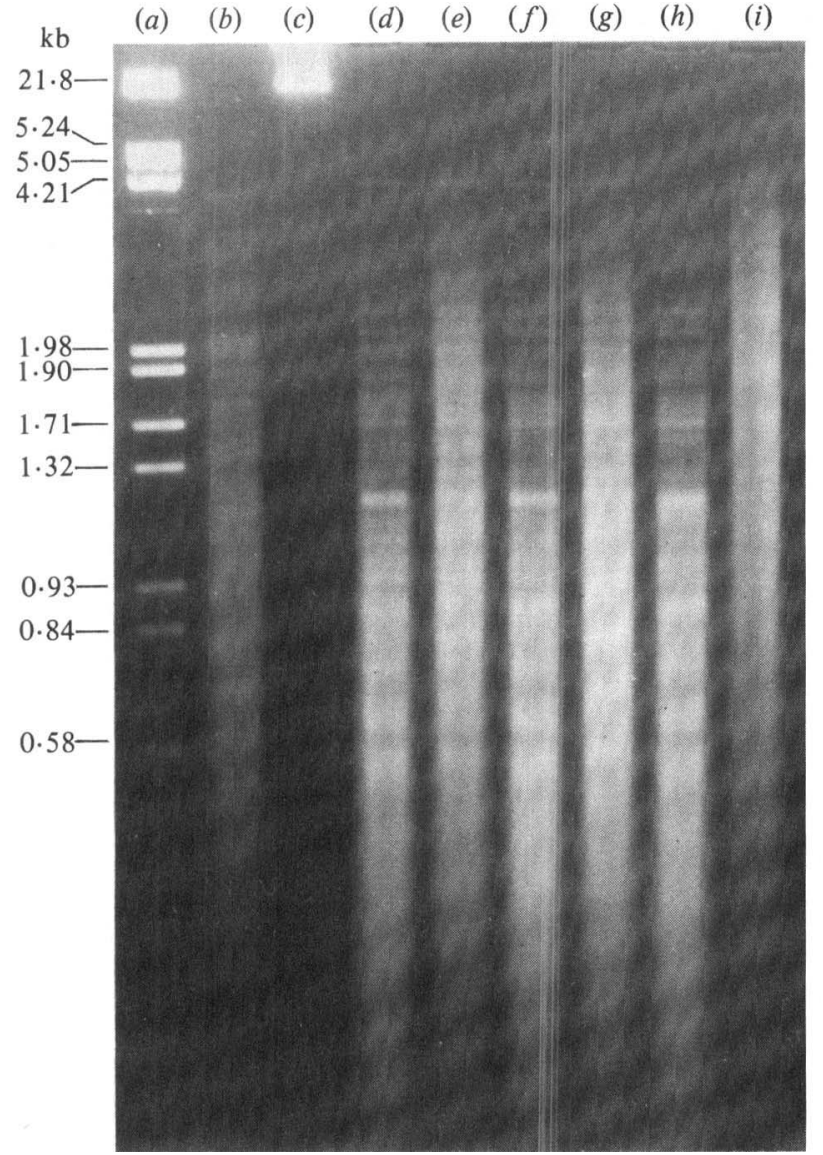

Fig. 6. Bst NI and EcoRII digests of DNA from $M$. tuberculosis strains, size-fractionated on a $2 \%$ agarose gel. Bacteriophage $\lambda$ DNA digested with HindIII and EcoRI was used as size markers (lane $a$ ). Lanes: $(b)$ and (c) E. coli, Bst NI and EcoRII, respectively; $(d)$ and (e) $M$. tuberculosis H37Rv, Bst NI and EcoRII, respectively; $(f)$ and $(g) M$. tuberculosis H37Ra, Bst NI and EcoRII, respectively; (h) and (i) $M$. tuberculosis H4Ra, Bst NI and EcoRII, respectively.

procedures for polysaccharide removal which cause a substantial loss in the quantity of DNA recovered. Baess (1974) noted a loss of $57 \%$ of BCG DNA after the first CTAB precipitation; in the present studies, $84 \%$ of the DNA was lost during removal of polysaccharides.

The restriction endonuclease digestion patterns presented here allow for the differentiation of nine mycobacterial species. This study supports the status of $M$. avium, $M$. intracellulare and $M$. scrofulaceum as independent species because restriction endonuclease digestion patterns of DNA isolated from them were readily distinguishable. Moreover, the restriction enzyme digestion patterns indicated similarities between strains of the same species. The technique, however, is sensitive enough to detect strain differences, as has been reported by others for bacteria (Marshall et al., 1981; Mielenz et al., 1979; Meselson \& Yuan, 1968) and protozoans (Morel et al., 1980). Independent isolates of M. tuberculosis (H37 and H4) could be differentiated on the basis of their digestion patterns with HindIII and Bst NI. M. tuberculosis H37Ra and H37Rv could not be distinguished. Collins \& De Lisle (1984) have also used restriction endonuclease analyses to distinguish different isolates of $M$. tuberculosis.

Methylated nucleotides have been detected in $M$. tuberculosis strains H37Rv and H37Ra, $M$. smegmatis and $M$. phlei (Srivastava et al., 1981 ; Somogyi et al., 1982). In our studies, we could not demonstrate either $\mathrm{m}^{5} \mathrm{C}$ at three DNA sequences using three matched pairs of enzymes differing in their sensitivity to methylated nucleotides, or $\mathrm{m}^{6} \mathrm{~A}$ at one sequence. These results suggest that the appropriate pairs of restriction enzymes to determine the distribution of the methylated nucleotides are not available. The presence of $\mathrm{m}^{5} \mathrm{C}$ and its effects on gene regulation (Razin \& Friedman, 1981) and the inclusion of a plasmid (Crawford \& Bates, 1979) have been 
suggested as possible explanations for the virulence of strain H37Rv. In our electrophoretic analysis of undigested DNA from strain H37Rv, the presence of a plasmid could not be detected.

We are currently modifying our procedure to obtain DNA from $\boldsymbol{M}$. lepraemurium isolated from mouse tissue and $M$. leprae isolated from infected armadillo tissue and human biopsy specimens. Characterization of the genome from $M$. leprae would be particularly useful in establishing the successful in vitro cultivation of the aetiologic agent of leprosy. It would also be of value to identify mycobacteria in biopsy material based on the comparison of fragment patterns obtained by digestion of DNA with reference strains. This could be done by extracting DNA directly from biopsy material, assuming an adequate number of bacteria, or by first cultivating the organism in vitro. This technology also provides a means for the application of restriction endonuclease technology in the analysis of mycobacterial gene structure and genome organization.

This work was supported by the Leonard Wood Memorial (American Leprosy Foundation), the Lions Clubs International Foundation, the Tropical Medicine Center (The Johns Hopkins University, School of Hygiene and Public Health), Gulf Oil Company and ARES, Geneva, Switzerland.

We would like to thank Keith Peden for helpful discussions and critical reading of the manuscript.

\section{REFERENCES}

Ashwell, G. (1957). Colorimetric analysis of sugars. Methods in Enzymology 3, 84-85.

BAESS, I. (1974). Isolation and purification of deoxyribonucleic acid from mycobacteria. Acta pathologica et microbiologica scandinavica Section B 82, 780-784.

BARKSDALE, L. \& KIM, K.-S. (1977). Mycobacterium. Bacteriological Reviews 41, 217-372.

Bradley, S. G., Brownell, G. H. \& Clark, J. (1973). Genetic homologies among nocardiae and other actinomycetes. Canadian Journal of Microbiology 19, 1007-1014.

Collins, D. M. \& De Lisle, G. W. (1984). DNA restriction endonuclease analysis of Mycobacterium tuberculosis and Mycobacterium bovis BCG. Journal of General Microbiology 130, 1019-1021.

Crawford, J. T. \& Bates, J. H. (1979). Isolation of plasmids from myobacteria. Infection and Immunity 24, 979-981.

Gross, W. M. \& WAYNe, L. G. (1970). Nucleic acid homology in the genus Mycobacterium. Journal of Bacteriology 104, 630-634.

HILL, L. R. (1966). An index to deoxyribonucleic acid base compositions of bacterial species. Journal of General Microbiology 44, 419-437.

Hill, E. B., Wayne, L. G. \& Gross, W. M. (1972). Purification of mycobacterial deoxyribonucleic acid. Journal of Bacteriology 112, 1033-1039.

IMAEDA, T., Kircheimer, W. F. \& Barksdale, L. (1982). DNA isolated from Mycobacterium leprae: genome size, base ratio and homology with other related bacteria as determined by optical DNADNA reassociation. Journal of Bacteriology 150, 414417.

LENNOX, E. S. (1955). Transduction of linked genetic characters of the host by bacteriophage P1. Virology 1, 190-206.

Macher, A. M., Kovacs, J. A., Gill, V., Roberts, G. D., Ames, J., Park, C. H., Strauss, S., Lane. H. C., Parillo, J. E., Fauci, A. S. \& Masur, H. (1983). Bacteremia due to Mycobacterium avium-intracellulare in the acquired immunodeficiency syndrome. Annals of Internal Medicine 99, 782-785.
Marshall, R. B., Wilton, B. E. \& Robinson, A. J. (1981). Identification of Leptospira serovars by restriction-endonuclease analysis. Journal of Medical Microbiology 14, 163-166.

Meselson, M. \& Yuan, R. (1968). DNA restriction enzyme from $E$. coli. Nature, London 217, 1110 1114.

Mielenz, J. R., Jackson, L. E., O’Gara, F. \& Shanmugan, K. T. (1979). Fingerprinting bacterial chromosome DNA with restriction endonuclease EcoRI : comparison of Rhizobium spp. and identification of mutants. Canadian Journal of Microbiology 25, 803-807.

Mizuguchi, Y. \& Tokunaga, T. (1970). Method for isolation of deoxyribonucleic acid from mycobacteria. Journal of Bacteriology 104, 1020-1021.

Morel, C., Chiari, E., Plessmann Camargo, E., Mattei, D. M., Romanha, A. J. \& Simpson, L. (1980). Strains and clones of Trypanosoma cruzi can be characterized by restriction endonuclease fingerprinting of kinetoplast DNA minicircles. Proceedings of the National Academy of Sciences of the United States of America 77, 6810-6814.

RAzIN, A. \& Friedman, J. (1981). DNA methylation and its possible biologic roles. Progress in Nucleic Acid Research and Molecular Biology 25, 33-52.

ROBERTS, R. J. (1983). Restriction and modification enzymes and their recognition sequences. Nucleic Acids Research 11 (Supplement), r135-rl67.

Somogyi, P. A., Maso Bel, M. \& Foldes, I. (1982). Methylated nucleic acid bases in mycobacterium and mycobacteriophage DNA. Acta microbiologica Academiae scientiarum hungaricae 29, 181-185.

Srivastava, R., Gopinathan, K. P. \& RamakrishNAN, T. (1981). Deoxyribonucleic acid methylation in mycobacteria. Journal of Bacteriology 148, 716719.

Syzbalski, E. H. \& Szybalski, W. (1979). A comprehensive molecular map of bacteriophage lambda. Gene 7, 217-270.

Takeya, K. \& Hisatsune, K. (1963). Mycobacterial cell walls. I. Methods of preparation and treatment 
with various chemicals. Journal of Bacteriology 85 , 16-23.

Thomas, M. \& Davis, R. W. (1975). Studies on the cleavage of bacteriophage lambda DNA with EcoRI restriction endonuclease. Journal of $\mathrm{Mol}$ ecular Biology 91, 315-328.

Vestal, A. L. (1975). Procedures for the Isolation and Identification of Mycobacteria. US Department of Health, Education and Welfare publication no. (CDC)77-8230. Atlanta: Center for Disease Control.

WAYNE, L. G. \& Gross, W. M. (1968a). Isolation of deoxyribonucleic acid from mycobacteria. Journal of Bacteriology 95, 1481-1482.

Wayne, L. G. \& Gross, W. M. (1968b). Base composition of deoxyribonucleic acid isolated from mycobacteria. Journal of Bacteriology 96, 1915-1919.

WoLINSKY, E. (1979). Nontuberculous mycobacteria and associate diseases (state of the art). American Review of Respiratory Diseases 119, 107-159.

Youssoufian, H. \& Mulder, C. (1981). Detection of methylated sequences in eukaryotic DNA with the restriction endonucleases $S m a \mathrm{I}$ and XmaI. Journal of Molecular Biology 150, 133-136.

Zakowski, P., Fligiel, S., Berlin, O. G. W. \& Johnson, B. L., JR (1982). Disseminated Mycobacterium avium-intracellulare infection in homosexual men dying of acquired immunodeficiency. Journal of the American Medical Association 248, 2980-2982. 